\title{
Mobile and Terrestrial but Firmly Rooted on the River Banks: Biological Anthropology of Lepenski Vir and the Iron Gates Gorge Mesolithic
}

\author{
Mirjana Roksandic \\ Department of Anthropology, University of Winnipeg, Winnipeg, Canada \\ Email: m.roksandic@uwinnipeg.ca
}

Received May $13^{\text {th }}, 2012$; revised June $12^{\text {th }}, 2012$; accepted June $22^{\text {nd }}, 2012$

\begin{abstract}
Archaeological interpretation often links both the European Mesolithic and the complexity with reduced mobility and permanent or semi-permanent settlements. The Iron Gates Gorge (IGG) Mesolithic, on the banks of the Danube, with substantial formal disposal areas for the dead and canonized architecture, especially as manifested at the site of Lepenski Vir, fully conforms to this notion. Different aspects of bioarchaeological analysis - when evaluated concurrently — offer a counter-intuitive picture: at the time of its most complex development, the site of Lepenski Vir represented a focal point for a larger, more mobile hunter-gatherer group that identified with the site, its burials and its smaller resident population. The article explores the evidence provided by human skeletal remains and possible reasons behind these contradictory results.
\end{abstract}

Keywords: Biological Anthropology; Bioarchaeology; Europe; Mesolithic; Lepenski Vir; Mobility; Hunter-Gatherers

\section{Introduction}

For a number of reasons-including excavation practices, resolution of the available documentation and the state of publication-human skeletal remains represent the most direct source of information on life and experience of the people who inhabited the Iron Gates Gorge in the Mesolithic and left behind impressive artistic achievements, habitation sites and burial grounds that bear witness to the complex world they created. Skeletal information - the ultimate material evidence of a life lived - is rarely fully integrated into archaeological research (Ogilvie, 2006; Sofaer, 2006), and while bioarchaeological data are recognized sources of information on diet, health and lifestyle (a good overview is provided by Larsen, 2002), the discipline offers little to the current ambition of anthropological archaeology to understand past societies as living, ever-changing entities. In the following pages, basing my discussion on skeletal evidence, I summarize the findings of biological anthropology research in its archaeological context and give one of more plausible pictures of regional developments that led to the formation of the Mesolithic village of Lepenski Vir at the time it reaches its fullest artistic and ritual significance. Careful examination of bioarchaeological data suggests that the Mesolithic complex of Lepenski Vir should not be regarded as a static entity, but rather as a cultural phenomenon that during its existence experienced continuous change in terms of both its mobility and its resource base. The pattern that bioarchaeological data suggest is counterintuitive: the major artistic and architectural developments on the site, associated with a specific locus - the Iron Gates Gorge - and a specific resource-fishhappens only when the major part of the population no longer inhabits the riverine sites and no longer subsists largely on fish. Thus the shift in mobility and economic pattern is not reflected in the material culture in a straightforward way. Rather, the burials at Lepenski Vir and the associated material culture could have represented the process of re-establishing the social bonds through enacting the past: a repository of social memory (sensu Van Dyke \& Alcock, 2003) and a focal point for group identity in the times of change.

Although the present study relies on biological data, it does not proceed through formal hypothesis testing for a number of reasons: our samples are not unbiased, they are relatively small, and formal hypothesis testing often precludes more engaged interpretation (Price, 1995). Most of all, the insights reported in this paper are a product of years of research, reading and pondering on the "thick" meaning (sensu Carr \& Case, 2006; Geertz, 1967) of the skeletal material in the Iron Gates Gorge; they are an attempt to discern what the observed patterning can tell us about the nature of these sites and their inhabitants. While incomplete and limited, the information embedded in human osteological material provides some interesting and unexpected insights into the significance and meaning of the Lepenski Vir site for its inhabitants and a larger group that identified itself with the site.

\section{The Iron Gates Gorge Mesolithic}

The four Mesolithic sites on the right bank of the DanubePadina, Lepenski Vir, Vlasac, Hajdučka Vodenica - (Figure 1) were characterized by a relatively large number of burials (30 to 140 each) and trapezoidal houses (Babović, 1997; Jovanović, 1966a, 1966b, 1967, 1968, 1969, 1970, 1974; Srejović, 1966, 1968, 1969, 1971, 1972), and - in the case of Lepenski Virwith elaborate large sculptures often representing fish and other river beings (Babović \& Srejovic, 1981). On a fertile plain downstream from the gorge, excavations at Schela Cladovei 


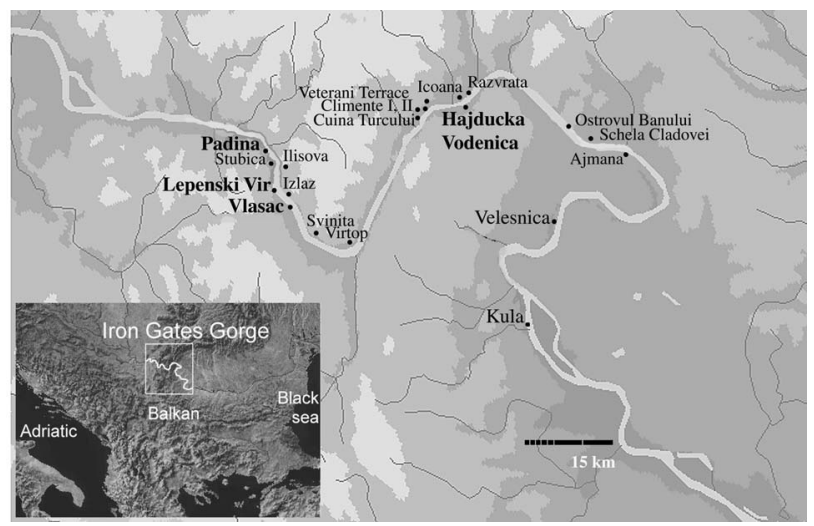

Figure 1.

The map of iron gates gorge with mesolithic and early neolithic sites (inset shows the Balkan peninsula with the position of the iron gates gorge).

unearthed more than 40 Mesolithic burials (Boroneanţ, 1973; Boroneanţ et al., 1999), while Ajmana and Velesnica, two Neolithic sites contemporaneous with Neolithic components of Lepenski Vir, were interpreted as showing similarities in architecture and burial practices with the IGG Mesolithic (Stalio, 1986; Vasić, 1986). Most of the early discussions centered on the Mesolithic vs. Neolithic nature of the sites. Concurrent with general developments in Mesolithic archaeology that no longer viewed this period as a prelude to the Neolithic, a more engaged interpretation of Iron Gates Gorge Mesolithic started to take shape in the late 1980s and early 1990s.

The paradigm change in the 1980 s that brought about increased interest in the Mesolithic populations was not the only reason to shift focus from farmers to indigenous hunter-gatherers in studying transition to the Neolithic in the Balkans. The Mesolithic IGG sites are the only sites in the region where contact between these groups could be traced archaeologically, through occurrence of items and features traditionally related to the "Neolithic package" in the Mesolithic context (see Bonsall, 2008; Bonsall et al., 2004, 2008; Borić \& Dimitrijević, 2007; Radovanović, 2006). While ${ }^{14} \mathrm{C}$ dates indicate contemporaneity of Mesolithic and Neolithic communities outside of the Iron Gates Gorge (Bonsall et al., 2004, 2008; Garašanin \& Radovanović, 2001; Radovanović, 2006; Tasić, 1997), the existing archaeological record does not offer any straightforward evidence of contact between hunter-gatherers and early food producers elsewhere in the region. As Radovanović (2006) pointed out, the few sites in the Morava valley, all of them Middle Neolithic, may only indicate a possibility of such a contact (the availability phase of Zvelebil, 1996), since the time of their occupation overlapped with the Late Mesolithic and Early Neolithic in the nearby Danube Gorges. Skeletal remains spanning this time period are not known from any other sites in the vicinity. Apart from the Anzabegovo material further south in the Skopska dolina, very few skeletal remains of Early Neolithic inhabitants of the Central Balkans are available (Borić, 1999; Stefanović, 2000), leaving us to look for patterns of interaction through comparison of pre- and post-contact archaeological and bioarchaeological data of the Mesolithic sites in the IGG.

There is little doubt in the current literature that an economy based on domesticated plants and animals was an import into the Central Balkans (Barker, 1985; Evans \& Rasson, 1984;
Gregg, 1988; Van Andel \& Runnels, 1995). Even the pig, which was considered as a locally domesticated species in the IGG (Bolomey, 1973), was shown to be an import (Boroneant \& Dinu, 2006; Dinu, 2006), leaving little doubt that the Neolithic moved into the Balkans as a developed phenomenon. Whether this movement happened through adoption of agriculture or actual movement of agricultural populations is still debated and unlikely to be resolved in the near future. While none of the authors excludes the possibility of "fluid boundaries" (Borić, 2005), dichotomy between foragers and farmers is a potentially useful and empirically valid analytical tool (Zvelebil \& Rowley-Conwy, 1986). According to Zvelebil and RowleyConwy's model, a small-scale society would depend on less than $5 \%$ of agricultural products in their diet in the availability phase due to some form of contact with a farming community; the substitution phase would include $5 \%-50 \%$ of domesticates; and the consolidation phase more than $50 \%$. A statistically negligible percentage of societies tabulated by Hunn and Williams (1982) reflected 5\% - 50\% participation of agricultural products (substitution phase), implying that this phase is unstable and probably of a very short duration. According to these data, small-scale societies would be either hunter-gatherers or farmers, not likely to exist for any longer period of time in the intermediary, unstable substitution phase (Rowley-Conwy, 2004; as summarised by Radovanović, 2006). This, of course, does not mean that societies can practice only one or the other type of subsistence consistently, or exclusively, but that the model will classify these societies based on the percentage of produced food. While classifications are not objective entities, they are commonly used in analytical procedures as they allow comparisons between different phenomena. Limited as these terms are, foragers, farmers, Mesolithic and Neolithic still confer a particular sets of meanings, and are used on a regular basis even by their most ardent opponents (see Roksandic, 2000a). The importance of populations practicing agriculture to our understanding of the dynamics of the Mesolithic groups does not stem from the notion of the frontier model that emphasizes resistance and subjugation, as suggested by Borić (2005), but from the fact that - even when there was no contact or active recognition - the existence of different subsistence practices in the same general area would have influenced how these groups perceived themselves and each other (Radovanović, 2006). While individual members of either group will not necessarily base their actions in opposition to the "others", a number of parameters in their everyday life would have changed and have repercussions on their understanding and expression of self. Thus the contact would have brought about changes and required a re-evaluation of the cultural norm for the groups involved. Radovanović's (1996) interpretation of greater ideological integration thus cannot be understood as "perpetuating this type of model... for the sake of proving acceptable, forcefully coherent and most of all recognizable accounts" (Borić, 2005). On the contrary, it provides a flexible framework for re-evaluation of personal experiences at the time of change. In this context "Contact" period should be understood as a time when actual physical contact of foraging and farming communities in the Balkans was possible, regardless of whether it happened or what particular form it took (see Roksandic, 2000a). The Mesolithic period is reserved for the Holocene huntergatherers in the region prior to the possible contact, and Neolithic for the communities whose subsistence relied on more than $50 \%$ of domesticated foods. Thus Mesolithic, Contact and 
Neolithic should be understood as potentially meaningful analytical units.

\section{Biodistance Studies}

Until relatively recently, studies of human skeletal material from the IGG sites were concerned with individual sites and conducted primarily within the paradigm of "anthropotypology" (Mikić, 1981; Nemeskeri, 1969; Nemeskeri \& Lengyel, 1978; Nemeskeri \& Szathmary, 1978c; Schwidetzky \& Mikic 1988; Živanović, 1976, 1979). As discussed elsewhere (Roksandic, 2000a), both Nemeskeri and Mikić were strongly influenced by Srejović's understanding of the archaeology of the region, and concerned with origins and in situ genesis of the IGG population. Regardless of paradigmatic shift and associated discourse, their data merit re-evaluation and possibly a reinterpretation.

Given the nature of skeletal collections and archaeological concerns with introduction of agriculture to the region, biodistance studies, which allow us to estimate the level of relatedness between different populations or individuals, seem to be a reasonable first step in analyzing population biology of the region. Two types of data - non-metric and metric - are used to analyze biodistance in archaeological populations, and there is a substantial body of literature arguing for their relative validity (see Buikstra et al., 1990). The following brief overview of their conceptual and methodological requirements for a nonspecialist stresses the utility of combining these different pathways of understanding in building archaeological interpretations. One could claim, at a very general level of archaeological inquiry, that the main conceptual difference between these sets of analyses is that non-metric (discrete, or epigenetic) traits require archaeologically determined populations as units of comparison, while metric data analyses use individuals within the population as units of comparison. Non-metric traits are threshold characters (De Stefano et al., 1984) expression of which depends on underlying genetic background (inheritance) and environmental conditions (nutrition, occupation, climate or any other factor and combinations of factors). Appearance of any set of traits in several individuals within a group cannot be used to argue fort their biological relatedness (Sjøvold, 1977); the units of analysis have to be pre-set archaeological subpopulations. The results obtained indicate whether cumulative traits for a sub-population A are similar or distinct to cumulative traits for a sub-population $\mathrm{B}$, or sub-population $\mathrm{C}$, and so on. It is critically important for this type of analysis that the sub-populations compared make "archaeo"-logical sense. The method works best when comparing large sub-samples or populations that can be easily distinguished temporally, geographically, or by their material culture. Graphic representation usually takes a form of a dendrogram or a multidimensional scaling plot (Sjøvold, 1984; Wilkinson et al., 1996). While no two populations will be exactly the same in terms of non-metric traits expression, close proximity on a dendrogram indicates relatedness, while a horseshoe pattern on the multidimensional scaling plot will be indicative of temporal change.

Analysis of non-metric traits (Figures 2(a) and (b)) suggested that the IGG Mesolithic/Contact/Neolithic population is best understood as an initially heterogeneous, single-breeding population (Roksandic, 2000a) that changed over more than 2000 years of more or less continuous occupation of the area. This temporal change is expressed by the Guttman effect (horseshoe

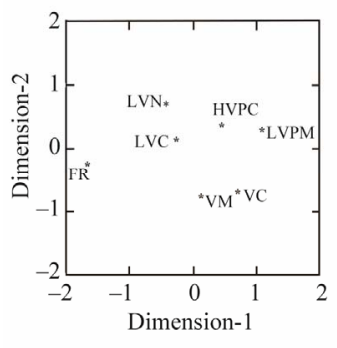

(a)

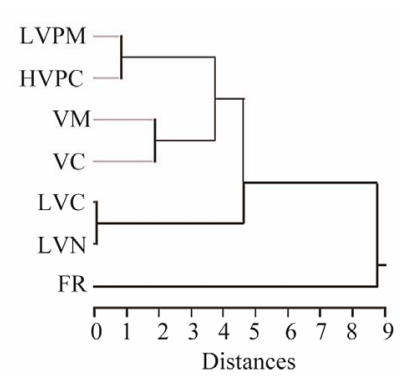

(b)
Figure 2.

(a) Multidimensional scaling plot and (b) Dendrogram of the MMD values for the site/chronology sub-samples (Adapted from Roksandic, 2000): LVPM = Lepenski Vir Mesolithic; LVC = Lepenski Vir Contact; LVN = Lepenski Vir Neolithic; HVPC = Hajdučka Vodenica Contact; $\mathrm{VM}=$ Vlasac Mesolithic; $\mathrm{VC}=$ Vlasac Contact; FR = Franzhausen, $\mathrm{a}$ Bronze Age site in Austria as an outlier (Wiltschke-Schrotta, 1992).

pattern) of the multidimensional scaling plot of site/chronology subgroups. The fact that at the time of the adoption of agriculture in the IGG we cannot perceive any substantial change in non-metric traits, strongly suggests that there is no abrupt change in population. Those who already lived in the general area most likely adopted agricultural practices without any influx of newcomers. A more pronounced population change happened at the time of the possible contact ("availability phase"), rather than at the time of the adoption of domesticates. This change could have resulted from two or more mutually non-exclusive processes: an influx of a new population into the area, and cultural integration over a larger area with an extension of marriage networks. When the same non-metric data discussed are represented as a dendrogram (Figure 2(b)) it can be more clearly observed that Lepenski Vir Contact and Lepenski Vir Neolithic individuals cluster together, and that they are removed from both the Mesolithic and the Contact populations at other sites in the region. The existing archaeological record shows that the adoption of farming (or husbandry) was accompanied by the adoption of the Middle Neolithic Starčevo material culture and burial practices between 5900 BC (Borić \& Dimitrijević, 2007) and 5500 BC (Garašanin \& Radovanović, 2001; Srejović, 1972). While it would be easy to interpret this pattern as an influx of "farmers" into the site of Lepenski Vir at the time of contact, the general lack of significant differences between the plotted values among the subgroups, as well as continuation of Lepenski Vir material culture, requires a less simplistic explanation.

A cautionary note is necessary here. It is quite possible that my assignment of individuals into one or the other period, while based on a thorough review of published and unpublished documentation, was incorrect. However, when compared to published dates (Bonsall et al., 2000, 2004, 2008; Borić \& Dimitrijević, 2007; Borić \& Miracle, 2004), only one out of 20 available dates was not in accordance with the period assigned on the basis of its stratigraphic position. Thorough analysis of unpublished documentation, moreover, brought into serious question the premature dismissals of Srejović's interpretation of stratigraphy at Lepenski Vir (Perić \& Nikolić, 2004). The result, while not conclusive, is encouraging; however, it is still possible that the picture would be different if absolute dates were available for each individual skeleton.

When examining metric data, the focus shifts to an individual 
as the unit of analysis. Multivariate statistics allow us to observe grouping patterns based on relative position of individuals on a plot. A re-examination of the available metric data from the sites, based on published measurements (Mikić, 1981; Nemeskeri \& Szathmary, 1978a, 1978b), is warranted as the authors used univariate statistics. I re-examined their metric data with Principal Components Analyses (PCA) and tests of variance to increase their interpretative potential and compared them with findings based on the measurements of the postcranial skeleton (Roksandic, 2000a).

In 1978 Nemeskeri and colleagues suggested that, both in blood types (Nemeskeri \& Lengyel, 1978) and metrics (Nemeskeri \& Szathmary, 1978a), women were more homogenous than men at Vlasac. While blood type analysis results are not deemed reliable, my own analysis of non-metric traits indicated that Contact period women in the IGG were less removed from Mesolithic men and women than Contact men (Roksandic, 2000a). Multivariate analysis of the postcranial data for the whole series confirmed the pattern (Figure 3), with women clustering together at one part of the diagram. All of this suggested a possibility of greater homogeneity of women and therefore a matrilocal residence pattern. However, the analyses of cranial metrics presented here resulted in a much more complicated picture that does not support this suggestion.

The PCA plot of neurocranial measurements (Figure 4) contradicts the statement that the "heterogeneity in absolute measures and indices is more significant in the case of males than in the case of females" (Nemeskeri \& Szathmary, 1978b: p. 178). On the first and second principal components, which explain $43 \%$ and $34 \%$ of the variation, we can observe a substantial overlap between males and females. A similar pattern is observed with second and third principal components. This explains why crania and postcrania produced different results in sex assessment. While male crania are a bit larger (more towards the right side of the diagram on the first component), the overlap is substantial. Male and female variances for the first three principal components were compared using a modified Levene's test based on the median rather than the mean. The assumption of normality for the sex-specific distributions of each principal component was assessed using a Wilks-Shapiro test prior to formal comparison of male and female variances. None of the sex-specific distributions deviated significantly from normality at the $\alpha=0.05$ level. None of the comparisons of male and female variances indicated a significant difference. Further comparisons based on chronology show that males clearly separate from females on the second component in the Mesolithic, and show strong overlap in the Contact period; the Neolithic sample is too small to allow any meaningful conclusions. Of interest for the Neolithic sample is that it is dispersed over the whole plot, countering the notion that the Neolithic group is a very different population (Grupe et al., 2003). This is important, as the trend we observe in both dietary analyses where Neolithic skeletons group together, and in the postcranial skeleton where Neolithic females group together in the lower range of size variation, could be misleading if taken at face value. Facial measurements and indices were available only for Vlasac, and show no significant differences in variance between males and females, although males can be distinguished on the basis of the size of mandible and maxilla more readily than is the case with neurocranial measurements.

Such strong differences between PCA plots based on neurocranial measurements ${ }^{3}$ and postcranial data require explanation.

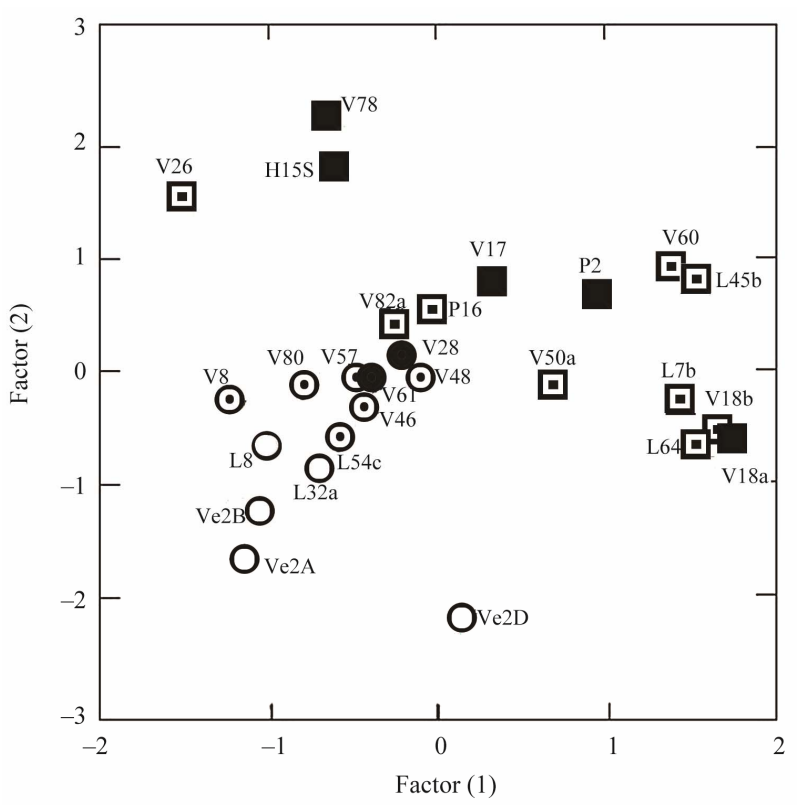

Figure 3.

PCA analysis of the postcranial measurements for the Iron Gates Gorge series. Squares: males; Circles: females; Black squares and circles: Mesolithic; White with a dot/square in the middle: Contact; White: Neolithic. Variables included in the analysis: Humerus maximal diameter, Radius anteroposterior diameter, femur maximum diameter of the head, femur anterior posterior subtrochanteric diameter, femur medial lateral subtrochanteric diameter.

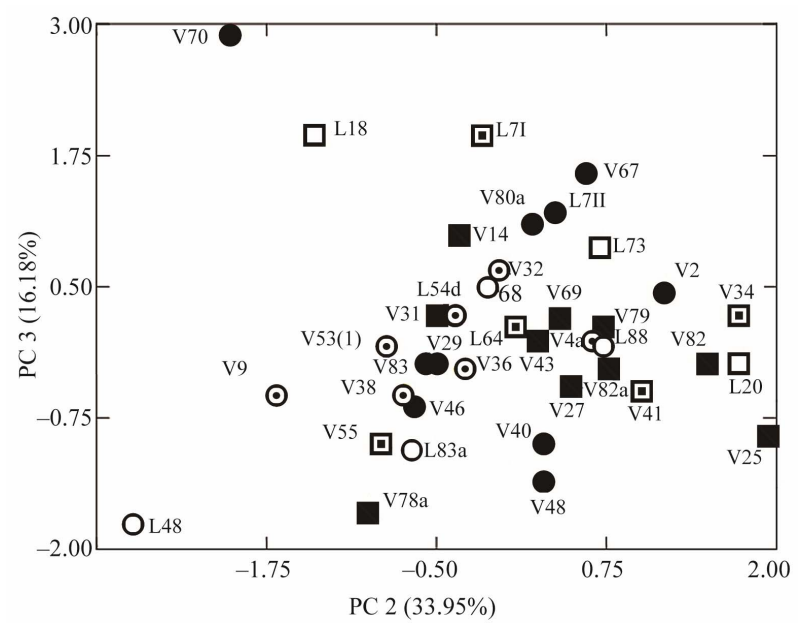

Figure 4.

PCA plot of neurocranial measurements. Components 2 and 3 that emphasize shape rather than size are presented. Squares: Males; Circles: Females. Black squares and circles: Mesolithic; White with a dot/ square in the middle: Contact; White: Neolithic; L = Lepenski Vir; V = Vlasac; Variables included in the analyses are Martin 1, 8, 9, 17, 20 and 26. Based on measurements by Nemeskeri and Szatmary (1978) and Mikić (1991).

We can exclude sampling error, as the observed discrepancy persists when we remove the individuals that do not have cranial measurements from the postcranial PCA plot. It is, therefore, most likely that we are dealing with different pressures affecting cranial and postcranial bones in which postcranial elements are likely to show greater growth plasticity and sus- 
ceptibility to environmental influences than the cranium. While there are no studies specifically examining the effect changes in the environment during ontogeny have on cranial size dimorphism, increased differences in postcranial size (particularly long bone lengths) do not necessarily mean that women and men were fed different diets, more likely men were more adversely affected by suboptimal environments, which results in reduced size dimorphism (c.f. Nikitovic \& Bogin, 2012).

\section{Diet}

Diet certainly played a significant role not only in skeletal plasticity, but also in our understanding of the Mesolithic/Neolithic interface. Diet and its implications for the mode of change from gathering to farming have been hotly debated for Western and Northern Europe (Milner et al., 2004; Richards \& Hedges, 1999; Richards \& Schulting, 2006) as well as for the Balkans (Bonsall et al., 1997, 2000; Borić et al., 2004; Grupe et al., 2003; Radovanović \& Voytek, 1997). These vivid discussions centered on three questions: 1) Was there a shift towards more terrestrial diet between early and later phases? 2) Were domesticates or wild animal species more responsible for the perceived shift? 3) What were the implications for the adoption of agriculture?

While these questions are no doubt extremely important, if we ignore them for the time being and concentrate simply on the patterning of the $\delta^{15} \mathrm{~N}$ and $\delta^{13} \mathrm{C}$ isotope values for individuals (Figure 5), we can perceive substantial differences in the dietary spectrum between the three examined sites: Lepenski Vir, Vlasac and Schela Cladovei. Schela Cladovei presents a very tight cluster of isotope values that match the relatively tight clustering of absolute dates of most burials, and strongly canonized burial practices (Boroneanţ, 1973, 1980; Boroneanţ et al., 1999). Vlasac, with larger number of individuals, greater

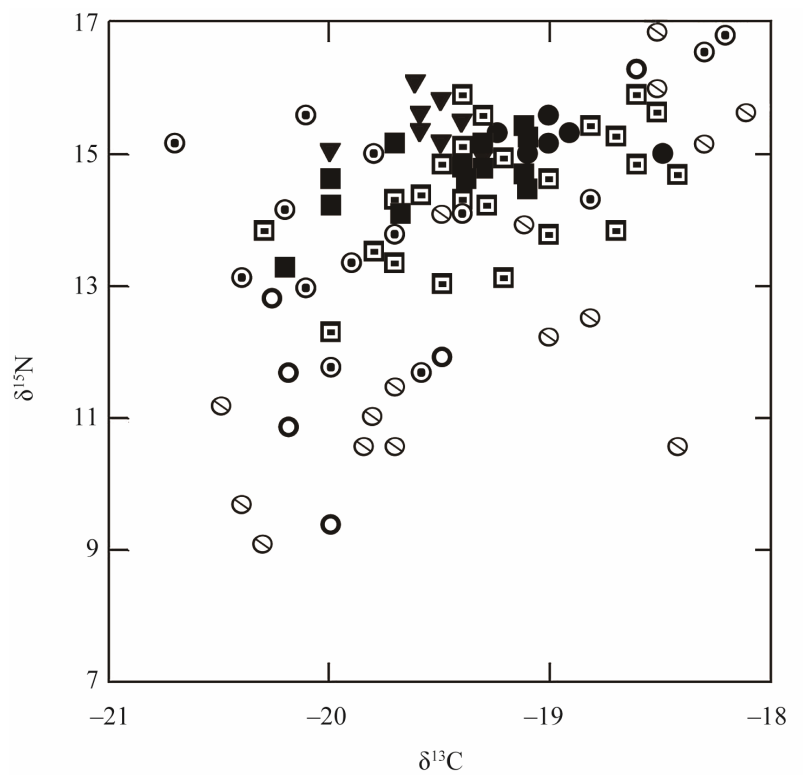

Figure 5.

Scatterplot of $\delta^{15} \mathrm{~N}$ and $\delta^{13} \mathrm{C}$ isotope values for Lepenski Vir, Schela Cladovei, and Vlasac; Circles: Lepenski Vir; Black: Mesolithic; White: Neolithic; White with a black dot: Contact; White with one line: Undetermined; Squares: Vlasac; Black: Mesolithic; White with a black square: Contact; Triangles: Schela Cladovei (all Mesolithic period burials). time depth, and more varied burial customs, still shows clustering: Mesolithic and Contact diets at this site overlap substantially with slightly more restricted range for the Mesolithic individuals, where fewer individuals show lower $\delta^{13} \mathrm{C}$ values. The Lepenski Vir pattern is the same as that of Vlasac for the Mesolithic period. Contact and Neolithic individuals show a significantly different distribution. As already observed by Bonsall and collaborators (2004), the diet of post-contact individuals at Lepenski Vir is far more varied than would be expected for a local sedentary group. Their observation holds true with inclusion of the additional data set from Borić and colleagues (2004). Bonsall and colleagues (2004) proposed a number of possible explanations: social, environmental and technological factors that could have induced Lepenski Vir inhabitants to diversify their resources. Environmental changes accompanied by a restriction of the available territory seem to be strongly supported by remains of material culture (see Radovanović, 2006 for discussion), with flooding as a major factor in near abandonment of the area between 6300 and $5900 \mathrm{cal} \mathrm{BC}$, as suggested by Bonsall and collaborators $(2000,2002)$. The exception would be the settlement of Lepenski Vir, where the duration of the climatic oscillation that brought about wetter conditions and floods corresponded to the time of construction of the Lepenski Vir I structures. The floors made of a heavyduty mixture of limestone and sand (Ney, 1971), unique in the whole Iron Gates area, represent Lepenski Vir at its most complex cultural manifestation. Construction of these sturdy floors at that particular time was interpreted as a protection of structures from being washed away by flooding (see also Chapman, 2000: p. 195) as was the displacement of the houses further up slope for both Lepenski Vir and Padina (Radovanović, 1996). While this scenario is plausible (for a critique see Borić \& Miracle, 2004), it is not critical for our argument here. It is just one of a number of other intrinsic and extrinsic factors that could have been responsible for a temporary change in the mobility pattern.

When proposing diversification of the resources at the site of Lepenski Vir as an explanatory mechanism for substantial dietary variation, Bonsall and colleagues did not consider another likely explanation, namely that this site-both as a burial ground and a focal point - attracted at this time a more dispersed group of individuals that identified themselves with Lepenski Vir. Thus a fully mobile hunter-gatherer population could have been using this "sedentary/semi-sedentary site" as focal points for burial of their select dead. This would account for the appearance at Lepenski Vir site at that time of individuals with "exotic" trace element signatures (Boric, 2006). As both dietary and non-metric traits suggest that population of Lepenski Vir during Contact times was more divergent from the preceding Mesolithic population and more variable than at other IGG sites, this explanation seems to me the most parsimonious.

\section{Demographic Data}

Based on discrepancy between fertility estimates obtained through calculation of juvenile/adult ratio (J/A) and mean childhood mortality (MCM) (Jackes, 2010), Jackes, Meiklejohn and I demonstrated a strong bias in the post-contact Lepenski Vir population, not observed in other periods at Lepenski Vir, or at other sites in the region (Jackes et al., 2008). The burial population of Lepenski Vir site does not represent an unbiased 
sample of the population that occupied the site. It represents a select group of individuals, but the selection was not necessarily based on age, sex or any other obvious attribute.

\section{Discussion}

Identification of Lepenski Vir as a site with a special ritual role in the landscape of the IGG hunter-gatherers has never been contested. What I suggest here, on the basis of bioarchaeological data, is that Lepenski Vir exerted this special ritual role at its pinnacle through a combination of limited resident population and a much larger non-resident, highly mobile population that identified with the site as an ancestral place of mythical and ideological prominence. That this happened at the time when possible environmental pressures forced them to change the way of life from a sedentary community with emphasis on fishing to a more mobile community with emphasis on terrestrial hunting and gathering is counter-intuitive, but not impossible. The change in itself could have been sufficient to prompt a more elaborate artistic representation of "the mythical past". Coupled with the appearance of a different mode of subsistence in the relative vicinity, it required a closer examination and adherence to the "olden ways" and a stronger identity building, as Srejović (1972) had already indicated. The observation that people from a larger territory identified themselves sufficiently with Lepenski Vir to bury their dead in the area with established lineage and ancestral significance signals that the site played an important role in the maintenance of group identity when the gorges themselves played an insignificant (or reduced) role in their subsistence. It could be claimed that the site(s) acquired this special role precisely because the ancestral territory and associated subsistence strategy and lifestyle were threatened. The IGG Mesolithic people who were forced at the time to observe a more mobile hunter-gatherer way of life, maintained group cohesion and identity by association with sites and objects that no longer played a role in subsistence, but increasingly in ideological integration based on ancestral territory and ancestral myth. This could explain the burst of artistic activity, and the fact that these symbolic, artistic endeavors were connected with fish which, while still no doubt included in the diet, no longer played a critical role in subsistence.

On a final note, archaeology is a discipline between art and science, and we can hardly hope to "prove" one scenario or another. It is per force circumstantial and depends on "thick" interpretation of available data. Biological anthropology, while firmly based in biological science, suffers no less from the same problems of interpretation. This paper presents one possible scenario, indicated by a number of analyses that taken individually could not be considered conclusive. When we consider the length of occupation of the Iron Gates gorge by the same Mesolithic group, alternating mobility should not be surprising. Given the nature of archaeological sites, it is relatively rare that archaeological or bioarchaeological data offer a glimpse into these changing conditions.

\section{Acknowledgements}

The initial study of the material was made possible by Wenner-Gren grant No. 6250. My sincere gratitude goes to Rastko Cvekić, Dejana Vlak and Dr. Michael Schillaci for numerous fruitful discussions and substantial comments on the first draft of this paper.

\section{REFERENCES}

Babović, L. (1997). Location and function of the Sanctuaries at Lepenski Vir. In M. Lazić (Ed.), Uzdarje dragoslavu srejoviću/antidoron dragoslavo srejović (pp. 97-108). Beograd: Filozofski Fakultet.

Babović, L., \& Srejović, D. (1981). Umetnost Lepenskog vira. Beograd: Narodni Muzej.

Barker, G. (1985). Prehistoric farming in Europe. Cambridge: Cambridge University Press.

Bolomey, A. (1973). An outline of the Late Epipalaeolithic economy at the "Iron Gates": The evidence of bones. Dacia N.S., 17, 41-52.

Bonsall, C. (2008). The Mesolithic of the iron gates. In G. Bailey, \& P. Spikins (Eds.), Mesolithic Europe (pp. 238-279). Cambridge: Cambridge University Press.

Bonsall, C., Cook, G. T., Hedges, R. E., Higham, T. F., Pickard, C., \& Radovanović, I. (2004). Radiocarbon and stable isotope evidence of dietary change from the Mesolithic to the Middle Ages in the Iron Gates: New results from Lepenski Vir. Radiocarbon, 46, 293-300.

Bonsall, C., Macklin, M. G., Payton R. W., Boroneanţ, A. (2002). Climate, floods and river gods: Environmental change and the MesoNeolithic transition in Southeast Europe. Before Farming, 3-4, 15.

Bonsall, C., Cook, G. T. et al. (2000). Stable Isotopes, radiocarbon and the Mesolithic-Neolithic transition in the Iron Gates. Documenta Praehistorica, 27, 119-132.

Bonsall, C., Lennon, R. et al. (1997). Mesolithic and Early Neolithic in the Iron Gates: A palaeodietary perspective. Journal of European Archaeology, 5, 50-92.

Borić, D. (2006). Cultural continuities and ruptures: Tradition, social memory and re-presentation in Balkan prehistory I. Lisbon: Union of Pre- and Protohistoric Sciences.

Borić, D. (2005). Deconstructing essentialism: Unsettling frontiers of the Meso-Neolithic Balkans. In D. Bailey, A. Whitlle, \& V. Cummings (Ed.), (Un)settling the Neolithic (pp. 16-31). Oxford: Oxbow Books.

Borić, D. (1999). Places that created time in the danube gorges and beyond, c. 9000-5500 BC. Documenta Praehistorica, 26, 41-70.

Borić, D., \& Dimitrijević, V. (2007). When did the "Neolithic package" reach Lepenski Vir? Radiometric and faunal evidence. Documenta Praehistorica, 34, 53-72.

Borić, D., \& Miracle, P. (2004) Mesolithic and Neolithic (dis)continuities in the Danube gorges: New AMS dates from padina and hajducka Vodenica (Serbia). Oxford Journal of Archaeology, 23, 341-371. doi:10.1111/j.1468-0092.2004.00215.x

Borić, D., G. Grupe, Peters, J., \& Mikić, Ž. (2004). Is the MesolithicNeolithic subsistence dichotomy real? New stable isotope evidence from the Danube gorges. European Journal of Archaeology, 7, 221248. doi: $10.1177 / 1461957104056500$

Boroneanţ, A., \& Dinu A. (2006). The Romanian Mesolithic and the transition to farming. A case study: The Iron Gates. Studii de Preistorie, 3, 41-76.

Boroneant, V. (1973). Recherches archéologiques sur la culture Schela Cladovei de la zone des "Portes de Fer". Dacia, N.S. 107, 5-39.

Boroneant, V. (1980). Probleme ale culturi Schela Cladovei-Lepenski Vir in lumina noilor cercetari. Drobeta, 4, 27-42.

Boroneant, V., Bonsall, C. et al. (1999). A Mesolithic burial area at Schela Cladovei, Romania. In A. Thévien, P. Bintz, \& A. Thévenin (Eds.), L'Europe des derniers chasseurs: Épipaléolithique et Mésolithique. Actes du 5 e colloque international de l'UISPP, commission XII, Grenoble 18-23 Septembre 1995 (pp. 385-390). Paris: Éditions du Comité des Travaux Historiques et Scientifiques.

Buikstra, J. E., Frankenberg, S. R. et al. (1990). Skeletal biological distance studies in American physical anthropology: Recent trends. American Journal of Physical Anthropology, 82, 1-7. doi:10.1002/ajpa.1330820102

Carr, C., \& Case, D. T. (2006). Gathering Hopewell. Society, ritual, and ritual interaction. New York: Springer Science and Media Inc.

Chapman, J. (2000). Fragmentation in archaeology, people, places and broken objects in the prehistory of South-Eastern Europe. London: 


\section{ROKSANDIC}

Routledge.

De Stefano, G. F., Hauser, G. et al. (1984). Reflections on interobserver differences in scoring non-metric traits (with practical examples). Journal of Human Evolution, 13, 349-355. doi:10.1016/S0047-2484(84)80041-X

Dinu, A. (2006). The question of pig domestication at Mesolithic Iron Gates. Ph.D. Thesis, Madison: University of Wisconsin-Madison.

Evans, R. K., \& Rasson J. A. (1984). Ex balcanis lux? Recent developments in Neolithic and chalcolithic research in Southeast Europe. American Antiquity, 49, 713-741. doi:10.2307/279738

Garašanin, M., \& Radovanović I. (2001). A pot in house 54 at Lepenski Vir I. Antiquity, 75, 118-125.

Gregg, S. A. (1988). Foragers and farmers: Population interaction and agricultural expansion in Neolithic Europe. Chicago: University of Chicago Press.

Grupe, G., Mikić, Z. et al. (2003). Vertebrate food webs and subsistance strategies of meso- and neolithic populations of Central Europe. In G. Grupe, \& J. Peters (Eds.), Documenta archaeobiologiae: Dechypering ancient bones (pp. 196-213). Rahden: Verlag Marie Leidrof Gmbh.

Hunn, E. S., \& Williams N. M. (1982). Introduction. North American and Australian hunter-gatherers (pp. 1-16). Canberra: Australian Institute of Aboriginal Studies.

Jackes, M. (2011). Representativeness and bias in archaeological skeletal samples. In S. C. Agarwal, \& B. A. Glencross (Eds.), Social Bioarchaeology (pp. 107-146). Hoboken: Wiley-Blackwell.

Jackes, M., Roksandic, M., \& Meiklejohn, C. (2008). The demography of the djerdap Mesolithic/Neolithic transition. In C. Bonsall, I. Radovanović, \& V. Boroneanţ (Eds.), Iron Gates gorge in the Mesolithic: New perspectives. BAR 1893 (pp. 77-88). Oxford: Archaeopress.

Jovanović, B. (1966a). Hajdučka Vodenica, praistorijsko nalaziste. Arheološki Pregled, 8, 102-103.

Jovanović, B. (1966b). Sculptures de la necropole de l'age du fer a Hajducka vodenica. Arcaeologia Iugoslavica, 7, 31-34.

Jovanović, B. (1967). Hajdučka Vodenica, nalazište gvozdenog doba. Arheološki Pregled, 9, 55-57.

Jovanović, B. (1968). Padina, naselje starijeg neolita i starijeg gvozdenog doba. Arheološki Pregled, 10, 89-93.

Jovanović, B. (1969). Padina, naselje starijeg neolita i starijeg gvozdenog doba. Arheološki Pregled, 11, 129-136.

Jovanović, B. (1970). Padina-Naselje mezolita, starijeg neolita i starijeg gvozdenog doba, rimska straza i ostava iz XIV veka. Arheološki Pregled, 12, 78-84.

Jovanović, B. (1974). Praistorija gornjeg Djerdapa. Starinar n.s., 22 , $1-22$.

Larsen, C. S. (2002). Bioarchaeology: The lives and lifestyles of past people. Journal Journal of Archaeological Research, 10, 119-166. doi:10.1023/A:1015267705803

Mikić, Ž. (1981). Djerdapska serija kao antropološki model neolitizacije. Glasnik Etnografskog Instituta SANU, 30, 103-130.

Nemeskeri, J. (1969). Stanovništvo Lepenskog Vira (Prethodni izveštaj). In D. Srejović (Ed.), Lepenski Vir (pp. 239-262). Beograd: Srpska Književna Zadruga.

Nemeskeri, J., \& Lengyel I. (1978). Laboratory examination on the vlasac bone finds. In D. Srejović, \& Z. Letica (Eds.), Vlasac. Mezolitsko naselje $u$ djerdapu (pp. 261-284). Beograd: SANU. 2 Geologija, Biologija, Antropologija.

Nemeskeri, J., \& Szathmary L. (1978a). Analysis of the variation of quantitative traits. In D. Srejović, \& Z. Letica (Eds.), Vlasac. Mezolitsko naselje u djerdapu (pp. 157-176). Beograd: SANU. 2 Geologija, Biologija, Antropologija.

Nemeskeri, J., \& Szathmary L. (1978b). Individual data on the vlasac anthropological series. Vlasac. In D. Srejović, \& Z. Letica (Eds.), Mezolitsko naselje u Djerdapu (pp. 285-426). Beograd: SANU. 2 Geologija, Biologija, Antropologija.

Nemeskeri, J., \& Szathmary L. (1978c). Taxonomical structure of the vlasac mesolithic population. In D. Srejović, \& Z. Letica (Eds.), Vlasac. Mezolitsko naselje u Djerdapu (pp. 177-229). Beograd: SANU. 2 Geologija, Biologija, Antropologija.

Ney, P. (1971). Mineralogische analyse einer fussbodenprobe von
Lepenski Vir I. In H. Schwabedissen (Ed.), Die anfaenge des Neolithikums vom orient bis Nordeuropa (pp. 33-34). Köln: Teil 2. Estliches Mitteleuropa.

Nikitović, D., \& Bogin, B. (2012). Ontogeny of sexual size dimorphism and environmental quality in Guatemalan children. 81 Annual Meeting of the American Association of Physical Anthropologists, Portland, 11-14 April 2012, 224

Ogilvie, M. D. (2006). Changing mobility roles at the advent of agriculture: A biobehavioral reconstruction, In F. Sellet, R. Greaves, \& P.-L. Yu (Eds.), Archaeology and ethnoarchaeology of mobility (pp. 155-183). Gainesville: University Press of Florida.

Price, D. T. (1995). Some perspectives on prehistoric coastal adaptations and those who study them. In A. Fischer (Ed.), Proceedings of the International Symposium, Kalundberg, Denmark 1993: Man and sea in the Mesolithic: Coastal settlements above and below present sea level (pp. 423-424). Oxford: Oxbow Books.

Radovanović, I. (2006). Further notes on Mesolithic-Neolithic contacts in the Iron Gates region and the Central Balkans. Documenta Prehistorica, 37, 1-8.

Radovanović, I., \& Voytek, B. (1997). Hunters, fishers or farmers: Sedentism, subsistence and social complexity in the Djerdap Mesolithic. Analecta praehistorica Leidensia, 29, 19-31.

Radovanovic, I. (1996). Iron Gates Mesolithic. Ann Arbor: University of Michigen Press.

Roksandic, M. (2000a). Between foragers and farmers in the Iron Gates gorge: Physical anthropology perspective. Documetna Prehistorica, $27,1-100$.

Roksandic, M. (2000b). Conference review: The Iron Gates in Prehistory, Edinburgh 30 March-2 April 2000. The European Archaeologist, 15, 14-15.

Schwidetzky, I., \& Mikić, Ž. (1988). Lepenski Vir und das Grazilisationsproblem in der Anthropologie. Godisnjak Centra za Balskanoloska ispitivanja ANUBiH, 24, 113-123.

Sjøvold, T. (1977). Non-metrical divergence between skeletal populations. Stockholm: Osteological Research Laboratory.

Sjøvold, T. (1984). A report on the heritability of some cranial measurements and non-metric traits. In: G. N. van Vark, \& W. W. Howells (Eds.), Multivariate statistical methods in physical anthropology (pp. 223-246). Dorchester: D. Reidel Publishing Company.

Srejović, D. (1966). Lepenski vir, Boljetin-Neolitsko naselje. $A r-$ heološki Pregled, 8, 94-96.

Srejović, D. (1968). Lepenski vir (Boljetin)—Predneolitska i neolitska naselja. Arheološki Pregled, 10, 85-87.

Srejović, D. (1969). Lepenski vir. Nova praistorijska kultura u Podunavlju. Beograd: SKZ.

Srejović, D. (1971). Predneolitske i neolitske kulture u Djerdapu. Materijali VIII kongresa arheologa Jugoslavije, 6, 21.

Srejović, D. (1972). Europe's first monumnetal sculpture: New discoveries at Lepenski Vir. Aylesbury: Themes and Hudson.

Stalio, B. (1986). Le site prehistorique Ajmana a Mala Vrbica. Djerdapske sveske-Cahiers des Portes de Fer, 3, 27-35.

Stefanović, S. (2000). Arheološki Istražene i antropološki obrađene nekropole na tlu srbije. Master's Thesis, Belgrade: Belgrade University.

Tasić, N. (1997). Apsolutna hronologija neolita centralnog Balkana, Ph.D. Thesis, Belgrade: Belgrade University

Van Andel, T. H., \& Runnels, C. N. (1995). The earliest farmers in Europe. Antiquity, 69, 481-500.

Van Dyke, R. M., \& Alcock, S. E. (2003). Archaeologies of memory. Oxford: Blackwell Publishers. doi:10.1002/9780470774304

Vasić, R. (1986). Compte-rendu des fouilles du site préhistorique à Velesnica 1981-1982. Djerdapske Sveske, Cahièrs des Portes de Fer, 3, 271-285.

Wilkinson, L., Blank, G. et al. (1996). Desktop analysis with SYSTAT. Upper Saddle River, NJ: Prentice Hall.

Wiltschke-Schrotta, K. (1992). Das fruhbronzezeitliche graberfeld von franzhausen $\mathrm{i}$, niederosterreich. 3. Untersuchung der epigenetischen merkmale. Anthropologischer Anzeiger, 50, 27-49.

Živanović, S. (1976). Ostaci ljudskih skeleta iz praistorijskog nalazista na Hajdučkoj Vodenici. Starinar, N.S., 26, 124-129.

Živanović, S. (1979). Further evidence on cromagnon in the Iron Gate 


\section{ROKSANDIC}

gorge of the Danube. Current Anthropology, 20, 805 .

doi:10.1086/202385

Zvelebil, M. (1996). What's in the name: the Mesolithic, the Neolithic and social change at the Mesolithic-Neolithic transition. In M. Edmonds, \& C. Richards (Eds.), Understanding the Neolithic of North-
Western Europe (pp. 1-35). Glasgow: Cruithne Press.

Zvelebil, M., \& Rowley-Conwy, P. (1986). Foragers and farmers of Atlantic Europe. In M. Zvelebil (Ed.), Hunters in transition (pp. 67-93). Cambridge: Cambridge University Press. 